日消外会誌 34 (11)：1635 1639，2001年

症例報告

\title{
CT，超音波検査および食習慣より術前診断しえた 柿結石による腸閉塞の1例
}

\author{
因島市医師会病院外科 \\ 内田一德 小川喜輝
}

\begin{abstract}
症例は55歳の女性 . 1988年 6 月膵頭部癌で膵頭十二指腸切除術 (Child 法) をうけ，以後再発なく12 年間経過した.1999年12月下旬, 嘔吐, 腹痛が出現し当科受診.腹部 Xp にて二ボーを認め腸閉塞の診 断で入院した . 保存的加療で症状は一時軽快したが, 再度嘔吐, 腹痛が出現し,CT にて小腸内に海綿 状腫瘤を認めた . 腹部超音波検査で，腸管内に音響陰影を伴う結石を確認した . 柿多食の病歴から， 柿結石による腸閉塞の術前診断で開腹術施行した . 術中所見では，屈曲した腸管内に，はまりこむよ うに黑褐色，鶏卵大の異物を認め，腸切開の上，摘出した . 摘出結石の成分分析は，タンニンが $98 \%$ 以上の柿結石であった . 術後 1 年 6 か月経過した現在も腸閉塞は来さず経過は良好である .
\end{abstract}

はじめに

胃石による小腸閉塞は極めてまれで，術前診断は困 難とされている.今回 , 我々は膵頭十二指腸切除術後 12年経過した症例で 柿胃石による腸閉塞を経験した . 術前 CT および摘出標本のCT で特徵的な形態を認め たので, 若干の文献的考察を加えて報告する .

症例

症例 : 55歳, 女性

主訴 : 嘔吐, 腹痛

家族歴 : 特記事項なし.

既往歴 : 昭和37年, 虫垂切除術

昭和63年, 膵頭部癌で膵頭十二指腸切除術平成 3 年 , 子宮摘出術, 両側卵巣摘出術

現病歴: 平成11年12月17日，腹痛，嘔吐が出現し当 科を受診した .腹部単純 $\mathrm{X}$ 線でニボーを認め腸閉塞と 診断し入院した。

入院時現症 : 貧血, 黄疸は認めず. 腹部は緊満, 腸 音は穴進し，右下腹部に圧痛を認めた . 腫瘤および筋 性防御は認めなかった .

血液生化学所見 : ChE が高值を示す以外は正常で あった .ChE 高值はChE-5の増加を認め遺伝性高 ChE 血症と診断した (Table 1).

入院時腹部単純 $X$ 線所見 : 右上腹部にニボーを認 めた (Fig. 1).

$<2001$ 年 7 月 30 日受理 $>$ 別刷請求先 : 内田 一德

７22-2211 因島市中庄町1962 因島市医師会病院外

科
入院後経過：胃管，イレウス管の挿入を患者自身が 拒否するため, 絶飲食の上, 保存的加療を開始した . 12月20日 ,排ガスを認め次第に腹部の緊満も消失した . 排便も認め症状も軽快し，流動食より徐々に経口捸取 を開始した．しかし，腸蠕動に一致した経度の腹痛は 依然持続していた。12月31日，再度腹痛か増悪し，腹 部 X 線にて二ボーを認め, 絶飲食の上, 再度, 保存的 治療開始した.1月 5 日, 腹部 CT 施行. 1月 7 日, 腹 部所見にて, 臍下部に弾性硬の腫瘤を触知し, 腹部超 音波検査施行した。

腹部 CT 所見 : 拡張腸管の肘門側に海綿状腫瘤を認 めた。壁は造影 CT では造影される外層と造影されな い内層の二層構造を呈し内部は不均一であった (Fig. 2).

腹部超音波検査所見 : 手術既往による腹壁と腹腔内 藏器の癒着は正中創下部にのみ認めた．CT での臍下 部の腫瘤に一致し，拡張腸管の肛門側に音響陰影を伴 う結石陰影を認めた (Fig. 3) .

以上の所見および今回の症状が発症する以前の 1 週 間に約30個におよう柿多食の病歴聴取で , 柿結石によ る機械的イレウスと診断し全身状態を改善した後，1 月14日，開腹術を行った。

手術所見 : 全身麻酔下に臍の上下 $10 \mathrm{~cm} に$ に開腹し た . 術前診断通り腹壁上腹部正中創下部にのみ癒着を 認めた 拡張腸管の先端は屈曲し腹壁に癒着しており， 内部に弾性硬の腫瘤を触知した . 腫瘤は腸管内を口側 へ容易に移動し腸切開の上これを摘出した (Fig. 4). 
Table 1 Laboratory data on admission

\begin{tabular}{lc}
\hline WBC & $8,600 / \mathrm{mm}^{2}$ \\
RBC & $394 \times 10^{4} / \mathrm{mm}^{2}$ \\
Hgb & $12.4 \mathrm{~g} / \mathrm{dl}$ \\
Hct & $39.1 \%$ \\
PIt & $26.3 \times 10^{4} / \mathrm{mm}^{2}$ \\
TP & $7.7 \mathrm{~g} / \mathrm{dl}$ \\
A Ib & $4.1 \mathrm{~g} / \mathrm{dl}$ \\
T bil & $0.4 \mathrm{mg} / \mathrm{dl}$ \\
A ST & $33 \mathrm{IU} / l$ \\
A LT & $33 \mathrm{IU} / l$ \\
LDH & $145 \mathrm{IU} / l$ \\
LAP & $114 \mathrm{IU} / l$ \\
A LP & $635 \mathrm{IU} / l$ \\
y-GT P & $58 \mathrm{IU} / l$ \\
ChE & $1,543 \mathrm{IU} / l$ \\
CA 19-9 & $26 \mathrm{U} / l$ \\
DUPA N-2 & $25 \mathrm{U} / \mathrm{l}$ \\
ChE isozyme & \\
ChE.1 & $3 \%$ \\
ChE.2 & $3 \%$ \\
ChE.3 & $3 \%$ \\
ChE.4 & $31 \%$ \\
ChE.5 & $51 \%$ \\
\hline
\end{tabular}

Fig. 1 Plain abdominal $X$-ray film shows multiple airfluid levels.

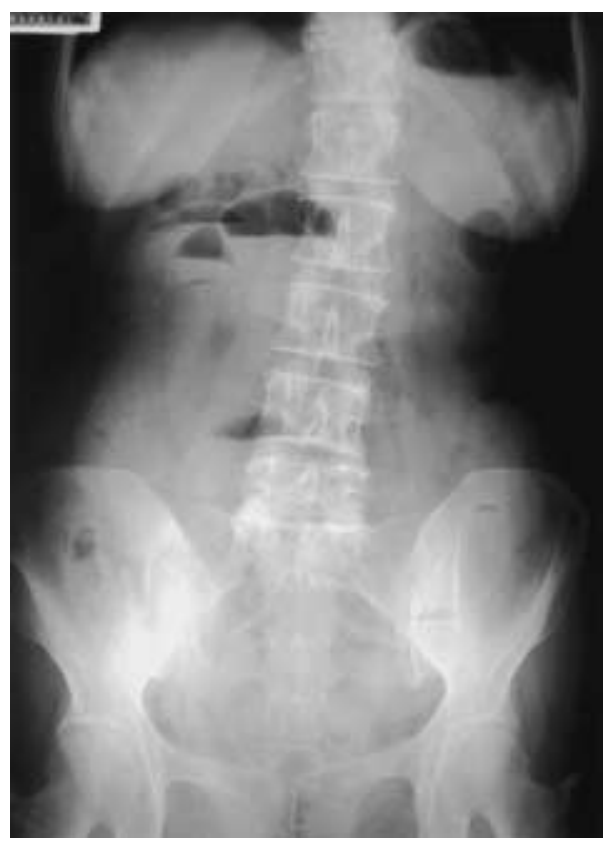

Fig. 2 CT revealed a sponge-like mass in the small intestine. CT of the outer layer was $+44.5 \mathrm{HU}$, and that of interior was $-15.6 \mathrm{HU}$.

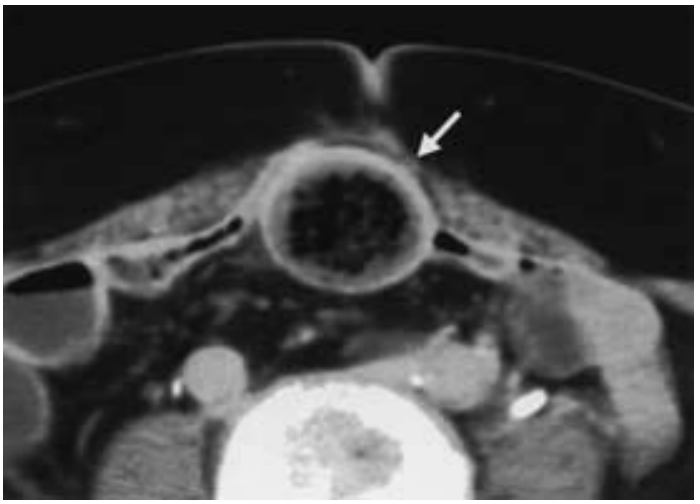

Fig. 3 Ultrasound showing an intraluminal echogenic mass with acoustic shadowing.
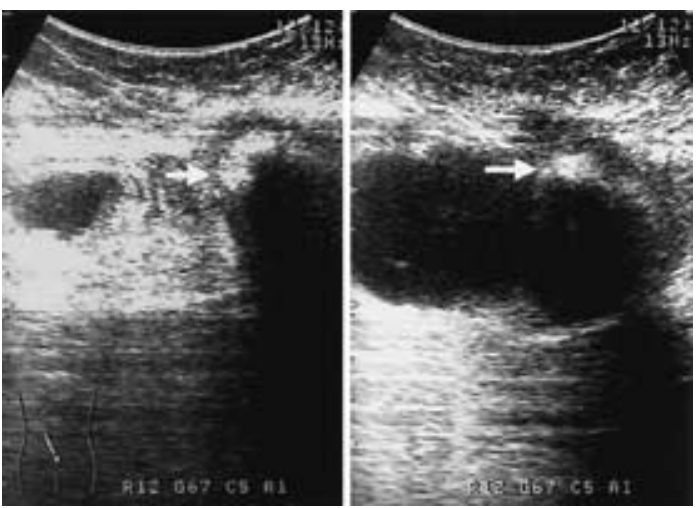

摘出標本 : 表面は凹凸不整, アボガド樣黑褐色で, $55 \times 30 \times 25 \mathrm{~mm}$ 大, 重量25g の弾性軟の結石であった . 割面は黄白色，踈な海綿状で纎維成分を認めた．核は 認めなかった (Fig. 5) .

結石成分分析 : $98 \%$ 以上がタンニンの柿石であっ た.

摘出標本 CT 所見 : 摘出標本の CT は術前 CT と同 樣に海綿状の腫瘤の像を呈した . 外殼は CT 值 +51.8 HU 内部の低吸収域は-22.8HUであつた (Fig. 6)

残胃透析所見 : 膵頭十二指腸切除術の再建は Child 法で行われ，十二指腸の切除は口側は幽門輪の直上か ら，肛門側はトライツ鞓帯の10cm 肛門側の空腸まで 行われた．胃透視では残胃は前庭部の一部を除き完全 
Fig. 4 A n egg-sized mass of for eign matter impacted the ileum.

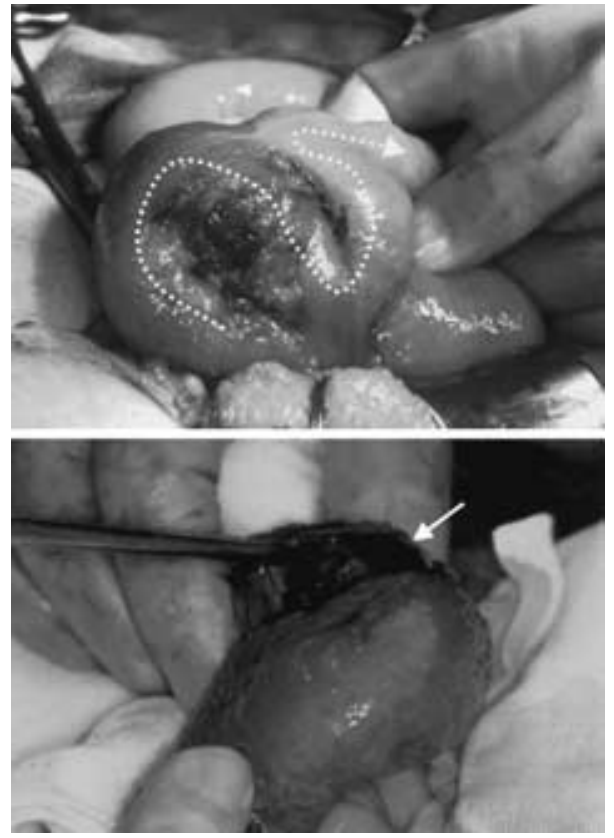

Fig. 5 A sponge-like $55 \times 30 \times 25 \mathrm{~mm}$ elastic soft mass weigh $25 \mathrm{~g}$ was removed.
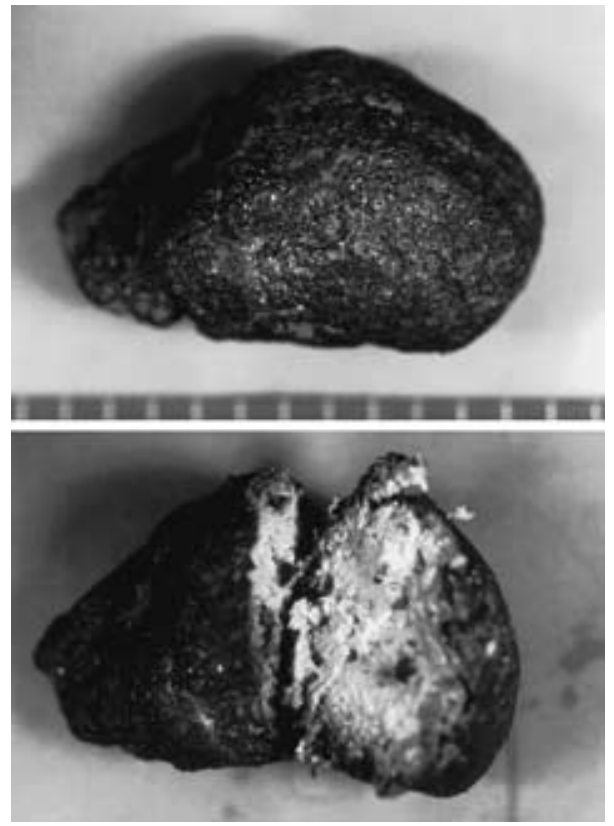

Fig. 6 CT of the outer layer of the specimen was + $51.8 \mathrm{HU}$ and that of the interior $\mathrm{w}$ as $-22.8 \mathrm{HU}$.

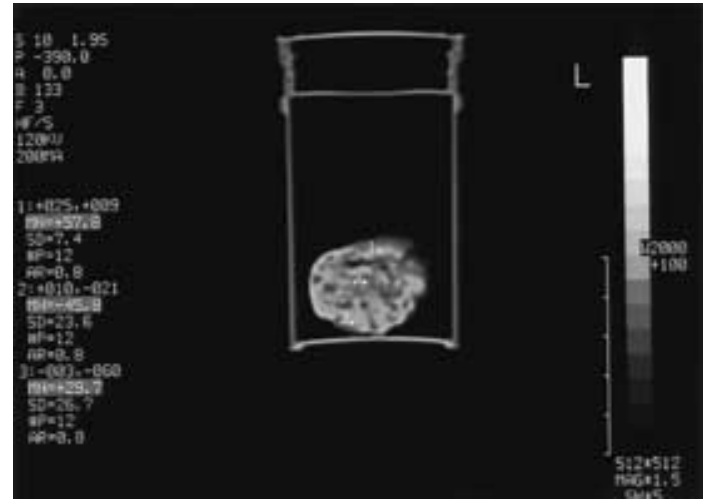

Fig. 7 A upper gastrointestinal series after pancreatico-duodenectomy. T he rest stomach was completely kept the shape except the pylorus ring.

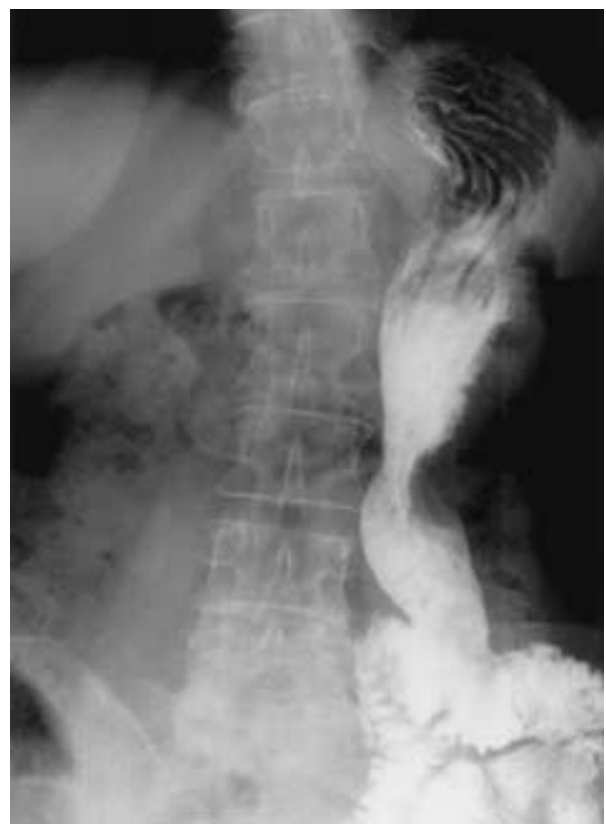

に残っていた．胃内の残椬貯留は認めず通過は良好で あった (Fig. 7).

\section{考察}

柿胃石は1962年の島谷ら ${ }^{1)}$ 報告では 本邦に多い疾 患とされていたが, 近年, 食文化の変化もあり, 比較 的まれな疾患とされている.胃石による腸閉塞はさら 
に稀で，胃石症例の 8〜10\%と報告されている213)．

柿胃石は, 空腹時に多量の柿攝取て好発し，比較的 短時間で結石化するとされている．これは，タンニン 酸が主成分である可溶性シブオールが胃酸によって不 溶性となり凝固・析出することにより形成されるとい う説 ${ }^{4}$ およびタンニン自体が胃内の酸性環境下で周囲 の高分子化合物と複合体を形成するという説が実験的 に証明されている5 。しかし, 正酸, 減酸例でも胃石は 形成され ${ }^{6 / 7)}$ ，糖尿病などによる胃排出時間の延長でも 形成されるとされている ${ }^{8)}$. 胃切除後や迷走神経切除 術後に発生する胃石は, A mjad ら ${ }^{9}$ か幽門括約筋作用 の消失による食物の不十分な混合と，迷走神経切離に よる胃運動の低下による食物の排出遅延，うっ滞によ り形成されるとしている．また，Sparberg ら ${ }^{10}$ は胃切 除による蛋白分離酵素の低下がこの成因としている． 後町ら ${ }^{11}$ は胃切除後は柿胃石が残胃に好発し, 容易に 胃腸吻合を通過し腸内に落下するために腸閉塞起こる と報告している．本症例も，膵頭部癌にて膵頭十二指 腸切除術を受けいる.この時の再建術式は減酸のため に全幹迷切を行いBraun 吻合を付加した Child 法で 行っており，低酸例における柿胃石形成例と考えられ る .十二指腸切除は口側は幽門輪直上で行われており， 残胃は幽門輪を除き完全に残っていた．また，胃内の 残椬貯留は認めず通過は良好であった .この点から， 本症例の結石形成は A mjad らの説が示唆され, 胃空 腸吻合を通過した柿胃石の下降による腸閉塞と考えら れた

入院時には鼓腸もあり臍下部の腫瘤には気付かな かった .これは開腹所見からも推察されるように，腫 瘤に可動性があり，入院当初は結石が移動していたた めに，症状が激烈には悪化せず，はっきりと腫瘤は触 知できなかったと考えられた．弾性硬の腫瘤が臍下部 に触知しえたのは入院後 3 週間経過した後であり，こ れは, 症状が再度悪化し結石が屈曲腸管にPacking したため，臍下部に腫瘤が触知可能となったと考えら れる .

今回の症例では造影 CT で腸管内に造影されない外 殻をともなう小腸内の海綿状腫瘤を認め， CT 值上か らは脂肪もしくは air を含む腫瘤と考えられ，小腸内 の残椬の塊と考えた．超音波検査では音響陰影を伴う 結石樣陰影を認め小腸結石と診断し，柿多食の病歴の 聴取で柿結石と診断した 摘出標本のCT は，摘出後の 乾燥のため外殼のCT 值が上昇しているが，ほぼ術前 CT の腫瘤と同樣に外款を有する海綿状腫瘤の像を呈
し，術前 CT で認めた腫瘤が柿結石であることを確認 した.諸家の報告にも同樣なCT像を認めてい $3^{12) ~ 16)}$. 迷走神経切離術や胃切除後の腸閉塞では, 稀 ではあるが柿結石による腸閉塞も念頭に入れ，柿多食 の病歴聴取および小腸内の海綿状腫瘤 CT 所見の確認 を行うことが術前診断に重要と考えられた。

\section{文献}

1) 島谷信人,島田彦造, 三宅新太郎,三原昭美 : 柿胃 石症の本邦報告例における統計的観察 . 消病の臨 $4: 749-760,1962$

2) 井上 直, 中谷守一, 吉岡幸男, 木下博明, 酒井克 治：胃石による小腸閉塞症の 1例 .日臨外医会誌 43 : 967-971, 1982

3) 駒田尚直,長島 明,山本政勝 : 柿胃石による腸閉 塞の一例 . 日消外会誌 $20: 1988-1991,1987$

4) 佐々木廸郎, 阪田唯祐, 永田剛昭: 柿石一光の生成 論一。外科 $28: 1033-1036,1966$

5) 泉 正一,岸本正樹, 石田吉治 : 植物胃石殊に果実 結石並びに其の結成機転に就いて . 日消病会誌 $30: 263-294,1931$

6) 多羅尾和郎,高邑佑太郎, 熊田淳一: 柿胃石の 1 例 ならびに本邦例に於ける統計的検討 . 横浜医 $12: 558-573,1968$

7) Silver BJ, Rhodes JB, Schimke RN et al : Bezoars : A complication of diabetic gastroparesis. J Kans Med Soc 84 : 249-250, 1983

8) Nichols TW Jr : Cimetidine and phytobezoarz. Lancet $9: 1263,1978$

9) A mjad H, Kumar GK, McCaughey R : Postgastrectomy bezoars. A m J Gastroenterol 64 : 327-331, 1931

10) Sperberg $M$, Nielssen $A, A$ ndruczak $R$ : Bezoar following gastrectomy. A m J Dig Dis 13 : 579, 1968

11) 後町洋一, 北鄉正亘 : 胃切除後残胃に発生した柿 胃石の 1例．胃と腸 6:81-84,1971

12）家接健一, 金子芳夫,田中松平ほか：腸閉塞を来し た残胃胃石症の 1手術例.日臨外医会誌 54 ： 664—668, 1993

13）小野寺健一, 日戶清敬：小腸閉塞を併発した柿胃 石の 1例 .日腹部救急医会誌 14：953-955, 1994

14）市場 洋,本田 宏, 林 武利ほか: 選択的迷走神 経切離術兼幽門形成術後25年目に発症した柿胃石 による腸閉塞の 1例 . 日臨外医会誌 57 ：24822485, 1996

15) 大瀧義郎,松田昌三,栗栖 茂ほか: 食物によるイ レウスの10例 .日臨外医会誌 58：606-611, 1997

16) 前田寿哉, 池田 裕, 木下欣也ほか: 術前 CT 撮影 にて消化管内異物か確認できた食䬲性イレウスの 1症例．日臨外医会誌 $54: 2116$-2119, 1993 
A Case Report of Intestinal Diospyr obezoar Obstruction, Preoper atively Diagnoted with

Computed T omogr aphy and UItr asound

\author{
Kazunori U chida and Y oshiteru Ogawa \\ Department of Surgery, Innoshima City Medical A ssociated Hospital
}

A 55-y ear-old woman undergoing pancreaticoduodenectomy 12 year s earlier was admitted with abdominal pain and nausea in December 1999. Plain abdominal radiography showed multiple air-fluid levels. A sponge-like mass was noted by computed tomography (CT ) in the small intestine. Ultrasound (US) of the mass showing an intraluminal echogenic mass with acoustic shadowing. Overconsumption of persimmons was confirmed in a detailed medical history intervuew. Surgery was conducted based on diagnosis of small bowel obstruction due to a diosphy robezoar. A dark brown egg-sized mass of foreign matter removed from the impacted ileum contained over $98 \%$ tannic acid.

Key words : diosphy robezoar, ileus, preoper ative diagnosis

〔Jpn J Gastroenterol Surg 34 : 1635-1639, 2001〕

Reprint requests : Kazunori U chida Department of Surgery, Innoshima City Medical A ssociated Hospital 1962 Nakanoshou, Innoshima city, 722-2211 JA PA N 